\title{
Popular Movement and Democratic Transition in Algeria: Opportunities and Challenges
}

\author{
SAFOU Mohamed \\ University of Oran 2-Algeria, PO box 36, Lardjem.38002, Algeria \\ Tel: 00213661055657 E-mail: medsafou2020@gmai.com
}

\begin{abstract}
:
Since its inception on February 22nd, 2019, the popular movement in Algeria has formed a new horizon for democratic change, by peacefully demanding a radical change of regime and the establishment of a new system in which only the people are the source of all power.

Despite the peaceful nature of the movement and its national character, it transcended all tribal, regional and ethnic affiliations and united on the need to move towards a democratic system of government.However, this has faced a set of challenges, perhaps the most important: the difficulty of controlling the relationship between civil and military in Algeria. It is difficult to confine the military's tasks to implementing the nation's defence policy. The military has become synonymous with the political system, and any successful democratic transformation must be negotiated.
\end{abstract}

Keywords: popular movement, democratization, military establishment

DOI: $10.7176 / \mathrm{JAAS} / 58-11$

Publication date:November $30^{\text {th }} 2019$

\section{Introduction:}

Since its independence on July 05th 1962, Algeria has been keen to adopt the one-party system (National Liberation Front) to manage the state. Justifyingthe latter based on the historical legitimacy on the one hand, and the promises made by the authority at that time by applying a development model that makes Algeria the Japan of Africa on the other hand. However, the political practice, after a quarter of a century, revealed a complex crisis that could plague the Algerian state. When power was diagnosed, society was excluded resulting in crisis of participation and the lack of justice in the distribution of wealth and its repercussions on the legitimacy of the political system as a whole.

The events of October 1988 marked the beginning ofan organized public protest against the negative performance of the regime on economic, political, social and identity levels.In response to these protest movements, the regime announced a series of political and economic reformswhose essence was the transition to pluralism and the adoption of a market economy system, as enshrined in the February 1989 Constitution.

Political pluralism did not provide a solution to the crisis, but increased its complexity of danger, especially after the obstruction of the electoral process in January 1992 and the resulting bloody situation and its high cost on security and economic, in other words it was a "national tragedy". To overcome this tragedy, the electoral process was resumed and the reconstruction of state institutions was initiated on the basis of popular legitimacy despite its shortcomings at that stage.Hopes were high for buildinga modern democratic state with the 1999 presidential election, compared to the high level of the political discourse and the promises made by the winning candidate, President Abdelaziz Bouteflika.

Once again, after 20 years of rule, and for four consecutive terms that almost ended with a fifth, the Algerians restored their demands for freedom, democracy and peaceful rotation of power, through a more organized and more comprehensive protest movement that began since February,22nd 2019, and continues its peaceful process despite the results Achieved.

What are the chances of this popular movement in the success of the democratic transition in Algeria, and what are the challenges facing it?

\section{Definition of the popular movement:}

It is a social phenomenon with political implications, based on the shift from a popularly unacceptable position to the search for an acceptable position within the political community, by adopting new and qualitative methods 
to effect change. The movement in its procedural sense is: abandoning the houses and homes that divide the public and dispersed it, and go down to public squares to convey one idea to those in charge of public affairs, its summary is, that it wants to participate in determining the general fate of the community1.

Here, the political content of the movement emerges. There is a social movement that rejects exclusion and marginalization and provides a political framework for the solution called political participation as an activity carried out by the citizens in order to influence the decision-making process. This includes the process of selecting the rulers themselves 2 and considers the democratic mechanism elections that will allow to embody the right to participate, which is something practiced by the Arab peoples for decades. This process did not make the nation a source of powerbecause of the systematic marginalization of people and depriving the Arabs from deciding their own fate. Thus, the election role was not assumed as a means of sharing or transferring power, it reproduced the ruling groups themselves in most cases3.

The continued confiscation of peoples' freedom and the marketing of false and fictitious achievements on the ladder of freedoms and high levels of development led to what is known as the shock of the Arab revolutions. The Arab peoples were no exception. The Arabs asked for equality with the rest of the globe, with whom they share the same aspiration for peace and prosperity4and the Algerian movement did not depart from these aspirations.

\section{Mobility, Revolution and Democratic Transformation:}

How can one classify the popular movement in Algeria? is it a revolution that will lead to a radical change of the political system or is it an attempt for democratic transformation in which the regime has the final say?.

Revolution : Without going into the linguistic meanings of the word revolution and its connotations of anger, frenzy and heart of things, we focus here on the word as a political and social term in the sense of radical change and coup, rebellion and regime change. The Arabs used the word exit to express the rebellion or revolution against the ruling and the existing regime5. In the same context, most contemporary thinkers have pointed out that the term is used to denote6:

2.1 - Sudden and Radical Changes :it takes place in social and political circumstances,: when the change of the existing rule happens suddenly and sometimes violently by another provision.

2.2 - Radical and Radical changes: Even if these changes have been slow and non-violent, such as a scientific revolution, a technical revolution, or a cultural revolution.

The Encyclopaedia of Sociology defines it as: "Radical changes in the institutional structures of society, changes that change society outwardly and substantially from a dominant pattern to a new one that conforms to the principles, values and ideology of the revolution. Fast, slow or gradual"7

\section{3- Democratic Transformation:}

According to Samuel Huntington, the first step on the subject of democratization is to clarify the meaning of democracy and transition to democracy8.

The concept of democracy was originally due to the Greek philosophers, and the modern use is linked to the

1-Mohamed Abdel Nour, Algerian mobility from a social perspective,Al Jazeera blogs 14/03/2019, link:https: //blogs,aljazeera.net Browsing date on 17/07/2019.

2-N. Nie, S, verba, "Political participation."

3-UNDP, Arab Human Development Report 2004 ,Towards Freedom in the Arab World, p. 09.

4-Mathieu Guidère, Le choc Des révolutions Arabes. Paris : Edition Autrement, 2011, p20.

5-Abdul Ghani Salameh, The Arab Revolutions Between Popular Will, Creative Chaos, Civilized Dialogue, Issue 3334,www.m.ahewar.org- 12/04/2011.

6 -Gamal Abdel Nasser, the philosophy of the revolution . Cairo: Arab House for Egyptian Documentation, 1996, p. 158.

7-Ramadan Abdel Salam Haidar ,revolutions of the Arab Spring and the future of the political system.

8-Samuel Huntington, the third wave: the democratic transition in the late twentieth century ,see: Abdul WahabAlloub, i 01: Cairo: Dar Souad al-Sabah, 1993, p. 64. 
revolutionary upheavals that occurred in Western societies at the end of the eighteenth centurylwhich revolve around the reshaping of governance in terms of source and purpose. The transition towards a rule is the will of the nation and its purpose is to serve the public interest.

The central measure of democracy is the selection of leaders through electoral competition, but do elections mean there is democracy?

The answer is absolutely no. Democracy also requires functioning institutions. It requires a legislative body representing the people, an independent judiciary that enforces the rule of law; free, independent, non-statecontrolled and corporate interests, and a vibrant civil society that can act as a guardian of government and interest groups, and provide alternative forms of political participation2. This provides the necessary balance against the possibility of a return to authoritarianism, and the risks of populism.

These requirements represent the scientific translation of the modern version of Joseph Schumpeter's concept of democracy. A democratic approach is to take institutional measures to reach decisions through which individuals gain decision-making power by competing for votes3. So democratic transformation is not merely a seasonal election, it is building institutions that guarantee freedom and integrity, respond to the needs of citizens and adapt to societal transitions.

The Algerian regime has failed to recognize the magnitude of the transformations taking place in society and to identify the forces of change led by young factions that cannot be intimidated by the past of the 'Black Decade', nor can their demand for freedom, democracy and radical regime change, be bought with political positions or financial returns. Thus, the popular movement is a revolution in its demands against the corruption of the system of governance in Algeria through the weakness of the existing institutions on the one hand, and the corruption of relations between them and citizens on the other4. It is peaceful in its expressive means and balanced in its strength with the existing regime to the extent that it requires dialogue between the various forces to agree on a comprehensive ground out of the crisis.

\section{The military establishment:}

After eight months of the popular movement, the military establishment has become the dominant actor in the political arena and has taken the initiative in full, based on the absence of a strategic vision of the movement, whether at the level of goals or at the level of leadership.

Despite the consensus on the departure of the existing regime and all its symbols, the fight against corruption in various sectors, and the building of a civilian state as opposed to military rule, this has not been translated into an alternative program led by a popularly supported leadership.

The Algerian army has gained its prestige and strength as an institution from its long history since independence, and from its unprofessional nature 5 .He continued to play advanced political roles despite constitutional provisions and political speeches confirming his non-interference in the political sphere.

Article 24 of the February 1989 Constitution defines the permanent mission of the National People's Army to maintain national independence and defend national sovereignty.It also defends the country's unity, territorial integrity and the protection of its land and air space.

This is a task confirmed by the 1996 Constitution and the various amendments it touched on, the most recent one being the 2016 amendment, where the previous article was copied in Article 28 without increase or decrease.

The task of defending the unity of the country, while suggesting to counter any external aggression and its occupation of certain parts of the national territory, seems to have been rubbery and can be loaded with any action, whatever its nature and whatever the source, may pose a threat to national unity.In this context, it is possible to include even the political opposition, which is inconsistent in its rhetoric and political behaviour with

1 -Ibid ,. P. 65

2 -Abdullah Atwi ,Population and Human Development .I, Beirut: Dar Al-Nahda Al-Arabiya, 2004, p. 851.

3 -Samuel Huntington, op.

4 -Nader Ferjany, "good governance in the Arab country ", in the Arab future , number 256, Beirut: Center for Arab Unity Studies, June 2000, p.08 .

5-SlimaneRiachi et al „.The Algerian crisis :political, social, economic and cultural backgrounds . Beirut :Center for Arab Unity Studies, 1999 , p. 63. 
the authority's discourse and approach.

It is this interpretation that has weakened the effectiveness of other institutions and rendered them incapable of keeping up with social transformations and responding to the aspirations of the Algerian citizen for freedom and dignity.Perhaps the most serious is the absence of representative institutions capable of containing and framing popular anger.All institutions and social forces have been emptied of their content and have become structures without a spirit .There are no opposition parties, no independent civil society, no free and fair media, and no independent judiciary.

The result: After thirty-six weeks of mobility, Algeria found itself facing a difficult equation from two sides:

-A broad popular movement that cannot be ignored, no matter how many, calls for radical regime change.

-A military institution that tries to preserve the state by imposing its strict regime on civilian life.

\section{4- The strategy of the military establishment in dealing with the popular movement:}

It is not possible to predict the independence of the Algerian movement without discussing the strategy of the army - as a strong institution in the regime - in dealing with the demands of the movement, and whether its accompanying and supporting the movement is a desire to maintain stability as an ultimate goal or just reproduce the same system with different faces.

The army's speech was confused at first, and described the rejectionists of Bouteflika's fifth election as being deceived, to witness the army changing perspectives, by adopting the demands of the people and confirming its legitimacy, where the Chief of Staff Lieutenant General Ahmed Qaid Saleh on March 26th, 2019 from the fourth military base confirmed that "the army's commitment to protect the people from all harm and any sort of danger". In this context, a solution must be adopted to ensure the exit from the crisis and to respond to the legitimate demands of the Algerian people, a solution that guarantees respect for the provisions of the Constitution and the continuity of the sovereignty of the State, a solution that will achieve the consensus of all and be acceptable to all parties. The solution provided for in the Constitution is Article 1021

This speech reveals the military's commitment to constitutional solutions to the crisis.Article 102 of the Constitution stipulates that the President of the Republic shall resign in the event of an impediment preventing the President of the Republic from exercising his duties. The Acting President of the Council of State shall be the Acting President of the Council of Nation. After the declaration of the Parliament in the two chambers, the majority of the members of the Chamber of Deputies shall be confirmed by a two-thirds majority (2/3).In the event of the continuation of the impediment after the expiration of forty-five (45) days, the vacancy shall be announced by resignation obligatory and the final vacancy of the presidency shall be established.The President of the Council of Nation shall assume the functions of Head of State for a maximum of ninety (90) days, during which presidential elections shall be organized2

The army also rejected all transitional phases, and called for activating the power of the people through Article 7 and Article 8 of the Constitution in a position that supports the absolute power of the people and reinforces the saying: Army-People, Khawa-Khawa (Brothers -Brothers).

Indeed, under the pressure of the military, the Algerian President resigned to the President of the Constitutional Council on April 02nd, 2019, announcing the vacancy that allowed Ben Saleh to become the head of state, and was set on 04 July 2019 as the date of the presidential elections, which the military establishment stressed the need to hold in time.

\section{5- Fighting Corruption:}

After Ben Saleh took office, the discourse on the power of the people retreated to fighting corruption as a cause of all the crises in Algeria. In this regard, General Ahmed Kayed Saleh stressed that: "All the indicators confirm that the economic crisis that our country is going through is mainly due to mismanagement by some officials who have lost all the elements of commitment, and did not take into account the weight of the responsibility they bear, as these were considered public money commons, but permissible from it as they want And what time they

1 -Speech Algerian Chief of Staff in 2019/26/03 on sitewww.tsa-algerie.comDate of review on 31/10/2019.

2 -Article 102, the Official Gazette Law No. 16-01 containing the constitutional amendment, number 14 of the.06.03.2016 
want and without supervision and uncontrollable"1.These practices have blocked the horizon for the Algerians and sent fear and despair to the future2.

Despite the importance of fighting corruption and dismantling its various financial, political and media arms, and the movement of justice based on heavy files and correct information that led to the deposit of many political officials and financiers temporary imprisonment, it has not yet recovered looted funds to support the national economy.

In this context, the strategy of the army did not deviate from the strategy of any regime facing popular rejection, and trying to absorb the anger of the street by fighting corruption and dwarf the demands of radical change of the system to the demands of factional and regional and identities.

\section{6- The question of identity in the popular movement:}

The issue of identity is one of the most serious challenges facing the democratic transformation in Algeria, because of its association with the process of building the national state based on its cultural identity.Thus, talking about the issue of Algerian identity recently becomes legitimate because the political situation can only recover if it is settled on an identity that gives representative legitimacy to political power.The State confiscated all the elements of identity (language and religion) and placed them in the public sphere, and the various constitutions followed this approach, and were enshrined in the last constitutional amendment of 2016, especially in Articles (2.3.3) and Article (6).

Article 02 states that Islam is the state religion.

Article 03 states: Arabic is the national and official language.

Article 04 also stipulates that Tamazight is also a national and official language.

If the national flag and the national anthem are the gains of the November 1954 revolution, as stated in Article 06 of the Constitution, which are unanimous, several regional banners appeared alongside the national flag. This is considered by the military establishment as a sensitive issue of trying to penetrate the marches and raising banners other than the national flag by a very small minority. The issue of the banner was then raised to distinguish between minority and majority in the same society, and to direct the movement to a national cause linked to the existence of a minority trying to strike national unity and dismantle the country.This trend was supported by the use of the term "the Zouaves" in accusing the tribesmen of treason, labour and stand with the French colonial against the liberation revolution.

In reference to the history of political crises in Algeria, we find them centred on the dimensions of identity, (the Amazigh demand in 1980, the abolition of the electoral process in 1992, the prevention of nonnational flags in 2019 and the bidding of nationalism to one party at the expense of others).

What must be emphasized here is that the movement is of a political nature to rebuild the national state on inclusive and strong foundations that enhance the political and social cohesion of the nation. The pluralism and diversity of society should not be employed to achieve immediate gains that would later reflect on national unity.

\section{7- Elections:}

After the failure to organize the elections scheduled to be held on 04 July on the constitutional date on 04 July 2019 due to the absence of candidates and the continued pressure from the popular movement, the PA returned again to present the presidential elections as the only democratic solution to resolve the crisis.President AbdelkaderBensalah has promised to provide all objective conditions with full impartiality and transparency.The democratically elected President of the Republic will undertake radical reforms to achieve the legitimate demands of the people. 3

This speech did not enjoy popular acceptance and the movement responded with the slogan: "No elections with gangs", referring to the impossibility of holding fair and transparent elections with the remnants of

\footnotetext{
1 -Address of Lieutenant General Ahmed Qaid Saleh, the third military aspect of Bashar on June 17, 2019

2 -Ibid.

3 -Full text of the speech of the President of the Algerian State on 03/07/2019
} 
the old regime, as it is not possible to build a new democracy with an old system. This trend was reinforced by the Chief of Staff's speech again on July 30, 2019, where he stressed the need to go to elections as soon as possible and without conditions.1

The call for elections was accompanied by the announcement of the establishment of a national committee for dialogue on 25/07/2019.It was headed by Karim Younes as a national figure who previously chaired the National People's Assembly (2002-2004).

The powers of this committee were not broad to address all the demands raised by the movement. It also did not receive sufficient popular support, and its role was limited to the preparation of the elections, as confirmed by the Chief of Staff of the National People's Army: "There is no room for further waste of time and elections are the key point on which dialogue should take place"2

The output of the Dialogue Committee was as it was intended, and supportive of the orientation of the presidential elections as the basis for the solution, and embodied this through:

7.1. Creation of the National Independent Authority for the Organization of Elections: It is an independent body with moral, financial and administrative autonomy. The powers of the independent authority are to embody and deepen constitutional democracy and promote the electoral system leading to peaceful and democratic circulation over the exercise of power3.Regardless of the composition of the commission and the circumstances surrounding its establishment, it is considered a democratic gain and a requirement of mobility related to the transparency and integrity of the electoral process. This authority prepares, organizes, administers and supervises elections, starting with the process of registering for electoral lists, voting, counting and settling electoral disputes4.

7.2.Amendment of the Electoral Law: The amendment of the Electoral Law 16-10 was in line with the establishment of the independent authority to organize elections to replace the administration to ensure transparency and integrity.Perhaps the most important amendment is related to the election of the President of the Republic. After the candidate was obliged to collect 60 thousand signatures, the number was reduced to 50,000 signatures. The second option concerning the collection of 600 signatures for the electors was abolished.In this context, article 142 of the amended law stipulates:

"In addition to the conditions specified in Article 87 of the Constitution, as well as the provisions of this organic law, a candidate must submit a list of at least fifty $(50,000)$ individual signatures to voters registered on an electoral list and must be gathered across at least 25 states. The minimum number of signatures required in each of the intended states shall not be less than 1200."5

The pace of these procedures was accelerated after the Chief of Staff's speech on 02/09/2019 and his emphasis on the need to call the Electoral College on 15/09/2019.This is what was already, where Abdel Qader bin Saleh announced the date of $12 / 12 / 2019$ as the date for the organization of the presidential elections.

\section{8- Civilization of the State:}

After successive weeks of popular movement, the demonstrators raised a new and worthy demand to build a civil state, not a military state, under the slogan "civil, not military."Far from intentions and backgrounds, the slogan poses a fundamental question related to the nature of the Algerian state.A civil state is the antithesis of a police or military state; there are basic standards that make the state civilian:

- Representation and compliance with the will of the nation.

- State of right and law.

- A system of fundamental freedoms (freedom of expression, freedom of movement and freedom of protest).

- Citizenship as a basis for social integration and political cohesion.

1www. Mdn.dz.site principale. 30/07/2019.

2ibid, 30/07/2019.

3-Article ,06 Official Gazette of the People's Democratic Republic of Algeria, Organic Law No. 19-07 of 14/09/2019, on the Independent Electoral Authority , No. 55, September 15, 2019.

4 -Article 07 ,op.

5 -The Official Gazette, Organic Law No. 08-19 corresponding to 14/09/2019, amending and completing Organic Law No.16-10. 
- Peaceful circulation of power.

By reference to these criteria, the term civil state can be used in theory, but is difficult to take in practice.There is sovereignty of authoritarianism, violation of human rights and lawlessness, and inequality1.

Conducting elections in the absence of these criteria, does not play its supposed role as a means of participation or the transfer of power2 and reproduce the regime itself, and pawns the future of democratic transition for long periods.

\section{9- Opportunities for democratic transformation:}

Opportunities for democratic transformation lie in the characteristics of the popular movement:

9.1 - Inclusiveness: It is represented in the national character of the movement. All protests in Algeria for decades were geographically limited (Kabylie, Ghardaia, and Ouargla).In addition, they were mainly centered on factional, professional and social demands 3 . This transcends traditional and narrow affiliations and brings together the need for political change.

9.2- Peacefulness: These demonstrations are held peacefully since the beginning of the movement the slogan "Peaceful-peaceful" is repeated as a principle that has become a process approach reflected in repeated calls not to respond to provocations and not to engage in confrontations with the security services. This underscores the Algerian people's awareness of the importance of peaceful protest and a stay away from violence, and thus democratic transformation can take place away from the violence and destructive chaos of states and nations.

9.3 - Diversity: This movement included all segments of society, including youth, elderly, elders, workers, unemployed, intellectuals and university students. This diversity has played a significant role in maintaining the peace and continuity of the movement, thereby strengthening the culture of participation imposed by democratic transformation.

9.4- Political Character: The movement started with clear political demands to reject the monopoly of power, reject the fifth term and move to the explicit demand for radical change of regime. This embodied the return of popular interest in political affairs after he resigned under the pressure of the black decade and the legacy of the national tragedy. The above characteristics can be built upon by creating the objective conditions for democratic transformation.

\section{0- Challenges:}

Although the aspiration to democracy is legitimate, but its embodiment remains a complex work, based on the set of obstacles and challenges facing it, and perhaps the most important:

10.1.-Difficulty in Controlling Civil-Military Relations: Based on Samuel Huntington's traditional theory, democratization depends on the principle of competence and professionalism. In the sense that the army should not engage in political life and its tasks are limited to the accomplishment and the implementation of the defence policy of the country4.

Despite the constitutional affirmation of the absence of any role for the military in political life, but the reality is quite different to that where the National Liberation Army played a paramount role in the independence of the country. After that, the PNA played a crucial role in the successive presidents coming to power. Houari Boumediene, Chedli Ben Jedid, and Yamine Zeroual were defense ministers before they took office. The appointment of the President of the Supreme Council of the State Mohamed Boudiaf, the election of Abdelaziz Bouteflika and his continuation of power from 1999 to 2019 did not depart from the support of the military

1-Arab Democratic Center, Analysis of the concept of a civil state, 14 July $2017 \mathrm{http} / /$ democraticac. de .Date: $05 / 11 / 2019$.

2 -United Nations Development Program, Arab Human Development Report 2004, Towards Freedom in the world Arab, p.09 .

3Louisa Ait Hamdouche, the popular movement in Algeria: between forced and contractual transfers .Doha: Al Jazeera Centre for Studies March 1920019 on Studies.a Ljazeera.net.

4 Ayat Atallah, Civil-Military Relations and their Impact on Democratization in Turkey .Berlin :Arab Democratic Center • May 2015.http :democraticac.d e / ? p 16273. 
establishment, until the resignation of the President and the completion of the draft of the fifth mandate by a decision of the army.

Perhaps the most realistic theory, in the Algerian case, is the theory of M. Janowitz, in which he sees the need for the participation of the military establishment in laying the foundations of a democratic system. It is difficult to treat the military as a neutral or mercenary entity carrying out security and defence policies, in exchange for material privileges and financial rewards1.The members of the Algerian army belong to the classes and classes of society are the people, not an independent group.

The role of the military cannot be confined to the defence of the country's borders and its security from the external enemy, but to safeguard the unity of the country and the cohesion of its people in times of crisis.

The main entry point for democratic transformation is negotiation and dialogue between the military as an actual authority on the one hand, and the various social and political forces on the other On the nature of the national state that can be built by activating the principle of the sovereignty of the people and serving the public interest, in which case the army can be the sole guarantor of democratic transition.

10.2-The relationship with the anti-movement forces: The movement was national in its early months, but began to decline with the emergence of factional and regional demands, which the regime employed to reproduce itself, which produced forces against democratic transformation. The size of its financial and media power cannot be ignored, forcing common ground and overcoming political differences even if elections are held on December 12, 2019.

An important lesson is that successful democratization must be a national property, including those who do not sympathize with democracy2, and it is important to facilitate the involvement of minorities, marginalized groups, youth and women in shaping democratization.

10.3- Economy: The economy is particularly important in weak or strong mobility. The transition to democracy can be undermined unless supported by economic achievements. Large groups of people have joined the popular movement from their dire economic and social conditions, and they are expected to achieve high levels of prosperity, economic growth, and development that directly reflect on their living standards.

Moody's said that the political crisis in Algeria is deepening economic and financial challenges and will pose a risk to the country's credit rating. "Investors are apprehensive, and domestic production capacity outside the energy sector has fallen by $50 \%$. If the crisis continues, there will be not only a decline in growth, but an economy that will face disaster," 3 said an economist and a member of the National People's Finance and Budget Committee.

The country's foreign exchange reserves fell to $\$ 72.6$ billion, a difficult situation for a country whose annual imports are estimated at about $\$ 40$ billion, meaning that the current reserves cover only 18 months of the country's needs.During the discussion of the budget for 2020, the Minister of Finance predicted the exchange reserve fund will collapse to $\$ 51$ billion by the end of 2020.In addition to the repercussions of this on the social situation, the high unemployment rates (12.5\%)4, especially among young people and university degree holders, and the widening of the social poverty circle to reach the category of retirees (3.2 million retirees), where the deficit of the National Pension Fund exceeded 600 billion dinars in 2019.

This demonstrates the fragility of Algeria's economic and social situation, a situation that discourages democratization. Economic growth, the equitable distribution of wealth, and the existence of the middle class are all objective conditions for the success of democracy. Anti-popular forces in Algeria can use these conditions to create a state of fear and economic security to break the steadfastness of the movement.

d-External challenge: International attitudes towards the popular movement in Algeria have not departed from accepted diplomatic principles.France has declared its confidence in the Algerian people and their ability to bring about peaceful democratic change. The United States of America announced its support for the Algerian people and their right to peaceful demonstration and the European Commission called to respect the freedom of

1civil- military relation, Wikipedia , (ac c ed on 07/11/2019).

2-United Nations Development Program, the International Forum on the paths of democratic transformation of June 2011, p.13 .

3 -How did the popular movement in Algeria affect the economic situation?https://arabic.euronews.com Date of entry: 08/11/2019.

4 -The National Bureau of Statistics, August 2019. 
expression and assembly listed in the Algerian Constitution, and Russia and China followed in the same direction, because of their economic interests with Algeria.

Although the UAE and Saudi Arabia have not declared any official position towards the protests in Algeria, the popular movement rejects any interference in Algerian affairs, especially the UAE and Saudi position, which they see as suspicious and seeks to abort the Algerian movement1.International positions remain contingent on three variables: the economic interests of major countries, the flow of migrants, and the high risk of terrorism. If these interests are not guaranteed, the major powers will not hesitate to support any regime that achieves security and stability, whatever their authoritarian nature.

\section{Conclusion:}

The future of democratic transformation in Algeria is contingent upon the realization of its goals of radical change in the regime and the building of a new national state that preserves the dignity of the citizen.

The Algerian people, through peaceful and civilized movement, aspires to overcome the state of authoritarianism and backwardness through peaceful mechanisms of change, translated by profound reforms that embody the authority of the people and express their free will, and establish a society of justice and equality within the framework of the rule of rights and law.

Whatever the scenarios of the political crisis, and whatever the paths and results of the presidential elections scheduled for December 12th, 2019, dialogue and compromise to reach political consensus between the various actors in society is the necessary condition for the embodiment of a successful democratic transformation project that avoids Algeria more lost years.

1 -Al-Jazeera Center for Studies ,Popular Mobility in Algeria: Motives and Locals . studies.aljazeera.net, 03/2019Date of entry: 7/11/2019. 